\title{
IMPLEMENTASI MODEL PEMBELAJARAN KOOPERATIF TEKNIK JIGSA W UNTUK MENINGKATKAN MOTIVASI BELAJAR AKUNTANSI SISWA
}

\section{IMPLEMENTATION OF COOPERATIVE LEARNING MODELS USING JIGSAW TECHNIQUE TO IMPROVE STUDENTS MOTIVATION TO LEARN ACCOUNTING}

\author{
Oleh: M. Aditya Indra Kesuma \\ Jurusan Pendidikan Akuntansi Universitas Negeri Yogyakarta \\ aditya_indra61@yahoo.com \\ Prof. Sukirno, M.Si., Ph.D. \\ Staff Pengajar Jurusan Pendidikan Akuntansi Universitas Negeri Yogyakarta
}

\begin{abstract}
Abstrak
Penelitian ini bertujuan untuk meningkatkan Motivasi Belajar Akuntansi kelas XI IPS 1 Madrasah Aliyah Negeri Pakem Sleman Tahun Ajaran 2014/2015 dengan Implementasi Model Pembelajaran Kooperatif Teknik Jigsaw. Penelitian ini merupakan penelitian tindakan kelas (PTK) dengan subjek penelitian siswa kelas XI IPS 1 Madrasah Aliyah Negeri Pakem Sleman Tahun Ajaran 2014/2015 yang berjumlah 32 siswa. Penelitian ini dilaksanakan dalam dua siklus dalam dua pertemuan. Tiap siklus terdiri dari empat rencana tindakan yaitu: perencanaan, tindakan, pengamatan, dan refleksi. Kompetensi Dasar yang dipilih yaitu Mencatat Transaksi ke dalam Jurnal Umum. Pengumpulan data penelitian ini dilakukan dengan observasi dan angket. Analisis data yang dilakukan adalah analisis data kuantitatif dengan persentase yang dilakukan dengan menghitung skor Motivasi Belajar Akuntansi, menyajikan data dan penarikan kesimpulan. Berdasarkan hasil penelitian disimpulkan bahwa Implementasi Model Pembelajaran Kooperatif Teknik Jigsaw dapat meningkatkan Motivasi Belajar Akuntansi siswa kelas XI IPS 1 Madrasah Aliyah Negeri Pakem Sleman Tahun Ajaran 2014/2015 yang dibuktikan dengan adanya peningkatan persentase skor Motivasi Belajar Akuntansi dari sebelum Implementasi Teknik Jigsaw sebesar 72,71\% meningkat sebesar 3,12\% menjadi 75,83\% di siklus 1 . Peningkatan juga terjadi pada siklus I ke siklus II yaitu sebesar $6,05 \%$ atau dari $75,83 \%$ pada siklus I menjadi $81,88 \%$ pada siklus II.
\end{abstract}

Kata Kunci: Pembelajaran kooperatif, Jigsaw, Motivasi Belajar Akuntansi.

\section{Abstract}

This research aimed to improve students motivation to learn accounting of class XI IPS 1 Madrasah Aliyah Negeri Pakem Sleman Academic Year of 2014/2015 through the implementation of Cooperative Learning Model using Jigsaw technique. This research was Classroom Action Research and conducted in two cycles. The data collection techniques in this research were through observation and questionnaires. The data analysis technique was using quantitative data analysis with percentage. Based on the results of this research, it can concluded that implementation of Cooperative Learning Models using Jigsaw technique can improve students motivation to learn accounting of class XI IPS 1 Madrasah Aliyah Negeri Pakem Sleman Academic Year of 2014/2015, evidenced by an increase in the percentage of scores before Implementation of Accounting Learning Motivation Jigsaw Technique of $72.71 \%$ increased by $3.12 \%$ to $75.83 \%$ in cycle 1 . The increase also occurred in the first cycle to the second cycle is equal to $6.05 \%$ from $75.83 \%$ in the first cycle to $81.88 \%$ in second cycle.

Keyword: cooperative learning, Jigsaw, motivation to learn accounting 


\section{A. PENDAhuluan}

Model pembelajaran kooperatif merupakan model pembelajaran yang memungkinkan siswa belajar secara aktif dan partisipatif. Model pembelajaran ini memaksimalkan kegiatan belajar dengan cara mengelompokkan siswa dalam kelompok-kelompok kecil dan saling belajar bersama. Berbagai macam teknik dalam pembelajaran kooperatif diantaranya yaitu pembelajaran kooperatif teknik Jigsaw. Dengan menggunakan model pembelajaran kooperatif teknik Jigsaw, siswa dapat memusatkan perhatian selama pembelajaran sehingga pemahaman siswa terhadap materi dapat maksimal. Hal ini dapat dilihat dari adanya kerja sama antar siswa dalam pembelajaran kooperatif teknik Jigsaw sebagai upaya memahami konsep dalam materi pelajaran, kerja sama ini juga berpengaruh terhadap meningkatnya motivasi belajar siswa. Pembelajaran kooperatif teknik Jigsaw membuat siswa lebih banyak melakukan aktivitas belajar seperti bertanya kepada teman dibanding guru dan mampu menciptakan pembelajaran yang lebih menyenangkan (Made Wena, 2011: 197).

Berdasarkan pengamatan terhadap proses pembelajaran yang dilakukan saat observasi awal di kelas XI IPS 1 Madrasah Aliyah Negeri Pakem Sleman Tahun Ajaran 2014/2015, ditemukan masalah pada kelas XI IPS 1 yaitu siswa tidak aktif selama proses pembelajaran walaupun guru telah mendorong mereka untuk berani bertanya, menjawab, atau menyanggah pernyataan. Siswa lebih banyak diam saat pembelajaran berlangsung, bahkan saat menemui kesulitan mereka lebih memilih diam dan tidak bertanya kepada guru. Saat pembelajaran berlangsung, guru sering kali harus menunggu siswa untuk bertanya tentang materi pelajaran yang belum dipahami atau menjawab pertanyaan yang diberikan oleh guru. Bahkan guru telah memanggil nama siswa untuk diberi kesempatan menjawab atau bertanya, namun siswa tersebut hanya diam atau menjawab dengan ragu-ragu. Bila guru mengajukan pertanyaan lisan, hanya sekitar 5 - 6 siswa yang berani menjawab pertanyaan atau mengeluarkan pendapatnya. Dari 32 siswa di kelas, hanya sekitar 10-12 siswa yang aktif selama proses pembelajaran. Hal ini, menjadi tugas bagi guru tersebut untuk mencari model pembelajaran yang tepat sehingga siswa lebih aktif dan berkontribusi total dalam pelajaran.

Belum maksimalnya aktivitas belajar siswa tersebut disebabkan oleh beberapa faktor, antara lain kondisi psikologis siswa, media pembelajaran yang digunakan guru, dan cara guru mengajar di kelas. Selain itu, dalam mengajar guru belum menggunakan media pembelajaran yang bervariasi, sehingga siswa hanya membaca buku sebagai sumber belajar. Model pembelajaran konvensional yang diterapkan guru dengan model ceramah dan tanya jawab membuat siswa tidak aktif selama proses pembelajaran. Model pembelajaran konvensional yang digunakan terus menerus selama proses pembelajaran membuat siswa merasa jenuh dengan pelajaran yang disampaikan oleh guru sehingga belum mampu meningkatkan motivasi belajar siswa secara maksimal. Penggunaan media dan model yang tepat selama proses pembelajaran dapat meningkatkan motivasi belajar siswa.

Berbagai macam teknik dalam pembelajaran kooperatif diantaranya adalah teknik Jigsaw. Dalam model pembelajaran kooperatif teknik Jigsaw, siswa dibagi dalam kelompok asal kemudian berkumpul dalam kelompok ahli untuk bekerja sama mendiskusikan submateri yang dihadapinya. "Jigsaw terdiri atas siklus reguler dari kegiatan-kegiatan pengajaran, yaitu 
membaca, diskusi kelompok ahli, laporan tim ke pada kelompok asal, mengerjakan tes dan rekognisi tim" (Slavin, 2009: 241). Dengan penerapan teknik Jigsaw, siswa akan lebih banyak beraktivitas, karena siswa saling bekerja sama dalam kelompok untuk memahami submateri yang diberikan oleh guru. Model ini menempatkan siswa sebagai student centered dalam pembelajaran, di mana siswa diberi ruang untuk aktif selama proses pembelajaran berlangsung. Model ini menuntut guru agar dapat membimbing siswa dalam belajar kelompok. Menurut Slavin dalam Iskandar (2009: 102) pembelajaran konstruktivisme dalam pengajaran menerapkan model pembelajaran kooperatif secara ekstensif, atas dasar teori bahwa siswa akan lebih mudah menemukan dan memahami konsep-konsep yang sulit apabila mereka saling mendiskusikan konsep tersebut. Sesuai dengan analisis yang telah disebutkan, peneliti bermaksud melakukan tindakan kuratif melalui penelitian dengan judul "Implementasi Model Pembelajaran Kooperatif Teknik Jigsaw untuk Meningkatkan Motivasi Belajar Akuntansi Siswa Kelas XI IPS 1 Madrasah Aliyah Negeri Pakem Sleman Tahun Ajaran 2014/2015".

Tujuan dilakukannya penelitian ini adalah untuk meningkatkan Motivasi Belajar Akuntansi dengan Implementasi Model Pembelajaran Kooperatif Teknik Jigsaw pada siswa kelas XI IPS 1 Madrasah Aliyah Negeri Pakem Sleman Tahun Ajaran 2014/2015.

\section{B. MODEL PENELITIAN}

\section{Desain Penelitian}

Penelitian ini merupakan Penelitian Tindakan Kelas (Classroom Action Research). Pelaksanaan penelitian tindakan kelas ini dilakukan melalui dua siklus dimana tiap siklus terdiri dari 4 tahap yaitu :
(1) perencanaan, (2) pelaksanaan, observasi, dan (4) refleksi.

\section{Tempat dan Waktu Penelitian}

Penelitian ini dilaksanakan di kelas XI IPS 1 Madrasah Aliyah Negeri Pakem Sleman yang beralamat di Jalan Pakem, Turi, Harjobinangun, Sleman, Yogyakarta. Penelitian yang dilakukan meliputi tahap persiapan, pelaksanaan, hingga pelaporan, dilakukan pada bulan September 2014 sampai bulan Desember 2014. Tahap draft proposal hingga seminar proposal dilaksanakan pada bulan Oktober 2014, tahap penelitian pada bulan November 2014, dan tahap penyusunan skripsi pada bulan Desember 2014.

\section{Subjek dan Objek Penelitian}

Subjek dalam penelitian ini adalah Siswa Kelas XI IPS 1 Madrasah Aliyah Negeri Pakem Sleman tahun ajaran 2014/2015 yang berjumlah 32 siswa yang terdiri dari 16 laki-laki dan 16 perempuan. Objek penelitiannya adalah Peningkatan Motivasi Belajar Akuntansi siswa kelas XI IPS 1 Madrasah Aliyah Negeri Pakem Sleman melalui implementasi model pembelajaran kooperatif teknik jigsaw.

\section{Teknik Pengumpulan Data}

a) Observasi Partisipasif

Observasi partisipasi dalam penelitian ini dilakukan dengan mengikuti pembelajaran, untuk memperoleh data seputar pelaksanaan pembelajaran, penggunaan teknik pembelajaran, dan kesesuaiannya dengan rencana pembelajaran yang telah dirancang.

b) Angket

Angket digunakan untuk mengukur Motivasi Belajar Akuntansi siswa kelas XI IPS 1 Madrasah Aliyah Negeri Pakem 
setelah Implementasi Model Pembelajaran Kooperatif Teknik Jigsaw. Angket diberikan setelah pembelajaran selesai.

c) Dokumentasi

Dalam penelitian ini, dokumen yang digunakan adalah foto kegiatan pada saat penelitian.

\section{Instrumen Penelitian}

a) Pedoman Observasi

Observasi yang dilakukan membutuhkan pedoman tertulis yang memuat indikatorindikator yang akan diamati. Berdasarkan indikator-indikator yang telah ditetapkan sebelumnya maka aspek yang akan diamati yaitu tekun menghadapi tugas, ulet menghadapi kesulitan, memiliki minat terhadap pelajaran, lebih senang bekerja mandiri, cepat bosan pada tugas-tugas rutin, dapat mempertahankan pendapatnya, tidak mudah melepaskan hal yang diyakini dan senang mencari dan memecahkan masalah soal-soal. Untuk mendapatkan data yang diinginkan, peneliti membatasi penyusunan Pedoman Observasi hanya terkait dengan Motivasi Belajar Akuntansi siswa yang dapat diamati pada saat pembelajaran akuntansi berlangsung.

b) Angket

Instrumen penelitian berupa angket merupakan alat bantu yang digunakan dalam penelitian pada saat mengumpulkan data di lapangan yang digunakan sebagai informasi untuk mengetahui motivasi belajar dalam pembelajaran akuntansi. Angket yang digunakan peneliti berupa angket tertutup yaitu angket yang telah dilengkapi dengan alternatif jawaban yang dapat dipilih oleh responden. Penyusunan angket pada penelitian ini adalah dengan menjabarkan setiap variabel penelitian ke dalam indikator - indikator yang akan diukur. Dari indikator akan dijabarkan menjadi butir - butir pernyataan.

\section{Prosedur Penelitian}

Pelaksanaan penelitian tindakan kelas mengikuti tahap-tahap penelitian yang pelaksanaan tindakannya terdiri atas beberapa siklus. Setiap siklus terdiri atas tahap perencanaan tindakan, pelaksanaan tindakan, observasi, dan refleksi. Dalam penelitian ini akan digunakan dua siklus penelitian.

\section{Teknik Analisis Data}

Teknik analisis data yang digunakan adalah analisis data kuantitatif. Data yang diperoleh dari lembar observasi dan angket adalah data kuantitatif, yang menunjukan penelitian atas kemunculan kegiatan yang mencerminkan Motivasi Belajar Akuntansi. Data yang diperoleh dari observasi dan angket selanjutnya akan dianalisis untuk mengetahui persentase skor motivasi siswa.

Langkah-langkah yang dilakukan dalam menganalisis data kuantitatif sebagai berikut:

a. Menentukan kriteria pemberian skor terhadap masing-masing indikator pada setiap aspek motivasi yang diamati

b. Menjumlah skor untuk masingmasing aspek motivasi belajar yang diamati

c. Menghitung skor motivasi belajar pada aspek yang diamati dengan rumus (Sugiyono, 2012: 137):

$\%=\frac{\text { skor hasil motivasi siswa }}{\text { skor maksimum }} \times 100 \%$

\section{Kriteria Keberhasilan Tindakan}

Dalam penelitian ini indikator keberhasilannya adalah meningkatnya motivasi siswa yang dicapai oleh siswa selama proses pembelajaran berlangsung dengan diterapkannya Model Pembelajaran Kooperatif Teknik Jigsaw pada kelas XI IPS 
1 Madrasah Aliyah Negeri Pakem dari siklus I ke Siklus II yang dihitung dengan persentase skor motivasi siswa pada aspek yang diamati. Tindakan ini dinyatakan berhasil sekurang-kurangnya diperoleh persentase Motivasi Belajar Akuntansi 75\%.

\section{HASIL PENELITIAN DAN PEMBAHASAN}

Berdasarkan analisis hasil penelitian diketahui bahwa terdapat peningkatan Motivasi Belajar Akuntansi siswa kelas XI IPS 1 Madrasah Aliyah Negeri Pakem Sleman. Hal ini dapat terlihat dari adanya peningkatan kegiatan yang mencerminkan motivasi belajar akuntansi yang dilakukan oleh siswa selama proses pembelajaran. Kegiatan yang dilakukan siswa telah memenuhi krtiteria yang ditetapkan dalam indikator-indikator tentang Motivasi Belajar Akuntansi dan menunjukan adanya peningkatan pada saat prasiklus ke siklus I dan dari siklus I ke siklus II. Peningkatan Motivasi Belajar Akuntansi yang terjadi dalam kegiatan pembelajaran akuntansi dapat terlihat dalam data berikut:

Tabel 1. Perbandingan Skor Motivasi Belajar Akuntansi Hasil Berdasarkan Observasi.

\begin{tabular}{|l|l|l|l|l|c|}
\hline \multirow{2}{*}{ Indikator } & \multicolumn{3}{|c|}{ Skor } & \multicolumn{2}{c|}{ Peningkatan } \\
\cline { 2 - 6 } & $\begin{array}{c}\text { Pra } \\
\text { siklus } \\
\text { I }\end{array}$ & $\begin{array}{c}\text { Siklus } \\
\text { I }\end{array}$ & $\begin{array}{c}\text { Siklus } \\
\text { II }\end{array}$ & $\begin{array}{c}\text { Pra } \\
\text { siklus } \\
- \\
\text { Siklus } \\
\text { I }\end{array}$ & $\begin{array}{c}\text { Siklus } \\
\text { I - } \\
\text { Siklus } \\
\text { II }\end{array}$ \\
\hline $\begin{array}{l}\text { Tekun } \\
\begin{array}{l}\text { Menghadapi } \\
\text { tugas }\end{array}\end{array}$ & $\begin{array}{l}77,08 \\
\%\end{array}$ & $\begin{array}{l}80,21 \\
\%\end{array}$ & $\begin{array}{l}87,50 \\
\%\end{array}$ & $3,13 \%$ & $7,29 \%$ \\
\hline $\begin{array}{l}\text { Ulet } \\
\text { menghadapi } \\
\text { kesulitan }\end{array}$ & $\begin{array}{l}76,04 \\
\%\end{array}$ & $\begin{array}{l}77,08 \\
\%\end{array}$ & $\begin{array}{l}80,21 \\
\%\end{array}$ & $1,04 \%$ & $3,13 \%$ \\
\hline $\begin{array}{l}\text { Memiliki minat } \\
\text { terhadap } \\
\text { pelajaran }\end{array}$ & $\begin{array}{l}73,96 \\
\%\end{array}$ & $\begin{array}{l}75,00 \\
\%\end{array}$ & $\begin{array}{l}82,29 \\
\%\end{array}$ & $1,04 \%$ & $7,29 \%$ \\
\hline
\end{tabular}

\begin{tabular}{|l|l|l|l|l|l|}
\hline $\begin{array}{l}\text { Lebih senang } \\
\text { bekerja mandiri }\end{array}$ & $\begin{array}{l}68,75 \\
\%\end{array}$ & $\begin{array}{l}70,83 \\
\%\end{array}$ & $\begin{array}{l}79,17 \\
\%\end{array}$ & $2,08 \%$ & $8,34 \%$ \\
\hline $\begin{array}{l}\text { Cepat bosan } \\
\text { pada tugas- } \\
\text { tugas rutin }\end{array}$ & $\begin{array}{l}67,19 \\
\%\end{array}$ & $\begin{array}{l}74,48 \\
\%\end{array}$ & $\begin{array}{l}82,29 \\
\%\end{array}$ & $4,16 \%$ & $7,81 \%$ \\
\hline $\begin{array}{l}\text { Dapat } \\
\text { mempertahanka } \\
\text { n pendapat }\end{array}$ & $\begin{array}{l}71,88 \\
\%\end{array}$ & $\begin{array}{l}76,04 \\
\%\end{array}$ & $\begin{array}{l}81,25 \\
\%\end{array}$ & $4,16 \%$ & $5,21 \%$ \\
\hline $\begin{array}{l}\text { Tidak mudah } \\
\text { melepaskan hal } \\
\text { yang diyakini }\end{array}$ & $\begin{array}{l}77,08 \\
\%\end{array}$ & $\begin{array}{l}78,13 \\
\%\end{array}$ & $\begin{array}{l}81,25 \\
\%\end{array}$ & $1,05 \%$ & $3,12 \%$ \\
\hline $\begin{array}{l}\text { Senang mencari } \\
\text { dan } \\
\text { memecahkan } \\
\text { masalah soal- } \\
\text { soal }\end{array}$ & $\begin{array}{l}73,96 \\
\%\end{array}$ & $\begin{array}{l}77,08 \\
\%\end{array}$ & $\begin{array}{l}80,21 \\
\%\end{array}$ & $3,12 \%$ & $3,13 \%$ \\
\hline Skor rata-rata & $\begin{array}{l}\mathbf{7 2 , 7 1} \\
\%\end{array}$ & $\begin{array}{l}\mathbf{7 5 , 8 3} \\
\mathbf{\%}\end{array}$ & $\begin{array}{l}\mathbf{8 1 , 8 8} \\
\mathbf{\%}\end{array}$ & $\begin{array}{l}\mathbf{3 , 1 2} \\
\mathbf{\%}\end{array}$ & $\begin{array}{l}\mathbf{6 , 0 5} \\
\mathbf{\%}\end{array}$ \\
\hline
\end{tabular}

Sumber: Data Primer yang Diolah

Dari data di atas terlihat jelas adanya peningkatan Motivasi Belajar Akuntansi siswa kelas XI IPS 1 Madrasah Aliyah Negeri Pakem Sleman dengan implementasi Model Pembelajaran Kooperatif teknik Jigsaw. Secara detail data peningkatan Motivasi Belajar Akuntansi dapat dilihat melalui grafik berikut:

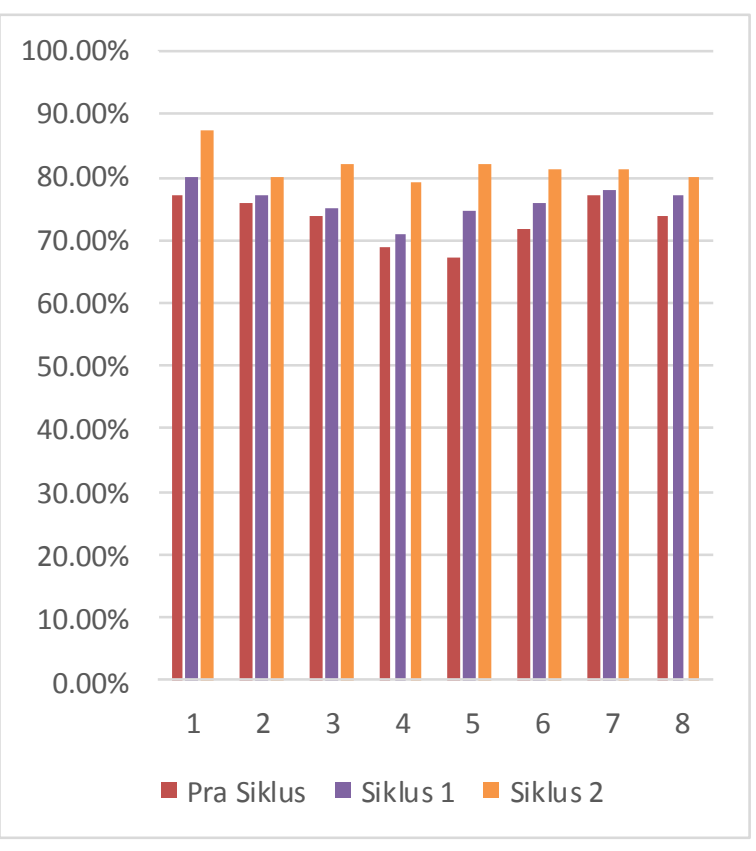


Gambar 1. Diagram Hasil Observasi Prasiklus, Siklus I, dan Siklus II

Sumber: Data Primer yang Diolah

Keterangan:

1 : Tekun Menghadapi tugas

2 : Ulet menghadapi kesulitan

3 : Memiliki minat terhadap pelajaran

4 : Lebih senang bekerja mandiri

5 : Cepat bosan pada tugas-tugas rutin

6 : Dapat mempertahankan pendapat

7 :Tidak mudah melepaskan hal yang diyakini

8 :Senang mencari dan memecahkan masalah soal-soal

Berdasarkan data di atas terlihat bahwa terjadi peningkatan skor Motivasi Belajar Akuntansi dari sebelum implementasi Pembelajaran Kooperatif Teknik Jigsaw ke siklus I sebesar 3,12\% dan dari siklus I ke siklus II sebesar 6,05\%.

Selain data dari observasi, tiap siklus juga diperoleh data dari angket yang diisi oleh siswa pada setiap siklusnya. Berdasarkan analisis hasil dari angket yang didistribusikan diketahui bahwa terdapat peningkatan Motivasi Belajar Akuntansi siswa kelas XI IPS 1 Madrasah Aliyah Negeri Pakem Sleman. Peningkatan Motivasi Belajar Akuntansi dari hasil distribusi angket dapat dilihat dalam data berikut:

Tabel 2. Perbandingan Skor Motivasi Belajar Akuntansi Berdasarkan Hasil Distribusi Angket

\begin{tabular}{|l|l|l|l|}
\hline \multirow{2}{*}{ Indikator } & \multicolumn{2}{|c|}{ Skor } & $\begin{array}{c}\text { Pening } \\
\text { katan }\end{array}$ \\
\cline { 2 - 3 } & Siklus I & Siklus II & \\
\hline $\begin{array}{l}\text { Tekun Menghadapi } \\
\text { tugas }\end{array}$ & $77.34 \%$ & $80.21 \%$ & $2,87 \%$ \\
\hline $\begin{array}{l}\text { Ulet menghadapi } \\
\text { kesulitan }\end{array}$ & $77.73 \%$ & $80.47 \%$ & $2,74 \%$ \\
\hline $\begin{array}{l}\text { Memiliki minat } \\
\text { terhadap pelajaran }\end{array}$ & $77.08 \%$ & $80.21 \%$ & $3,13 \%$ \\
\hline $\begin{array}{l}\text { Lebih senang } \\
\text { bekerja mandiri }\end{array}$ & $68.23 \%$ & $\mathbf{7 6 . 0 4 \%}$ & $7,81 \%$ \\
\hline $\begin{array}{l}\text { Cepat bosan pada } \\
\text { tugas-tugas rutin }\end{array}$ & $67.19 \%$ & $76.95 \%$ & $9,76 \%$ \\
\hline $\begin{array}{l}\text { Dapat } \\
\text { mempertahankan } \\
\text { pendapat }\end{array}$ & $72.14 \%$ & $\mathbf{7 9 . 6 9 \%}$ & $7,55 \%$ \\
\hline $\begin{array}{l}\text { Tidak mudah } \\
\text { melepaskan hal } \\
\text { yang diyakini }\end{array}$ & $75.00 \%$ & $80.86 \%$ & $5,86 \%$ \\
\hline $\begin{array}{l}\text { Senang mencari } \\
\text { dan memecahkan } \\
\text { masalah soal-soal }\end{array}$ & $75.39 \%$ & $81.25 \%$ & $55,86 \%$ \\
\hline Skor Rata-rata & $\mathbf{7 3 , 7 5 \%}$ & $\mathbf{7 9 , 3 8 \%}$ & $\mathbf{5 , 6 3 \%}$ \\
\hline
\end{tabular}

Sumber: Data Primer yang Diolah

Dari data diatas terlihat lebih jelas adanya peningkatan Motivasi Belajar Akuntansi siswa kelas XI IPS 1 Madrasah Aliyah Negeri Pakem Sleman. Peningkatan terjadi sebesar 5,63\% dari siklus I sebesar $73,75 \%$ menjadi $79,38 \%$ pada siklus II. Secara detail data peningkatan Motivasi Belajar Akuntansi dapat dilihat melalui grafik berikut: 


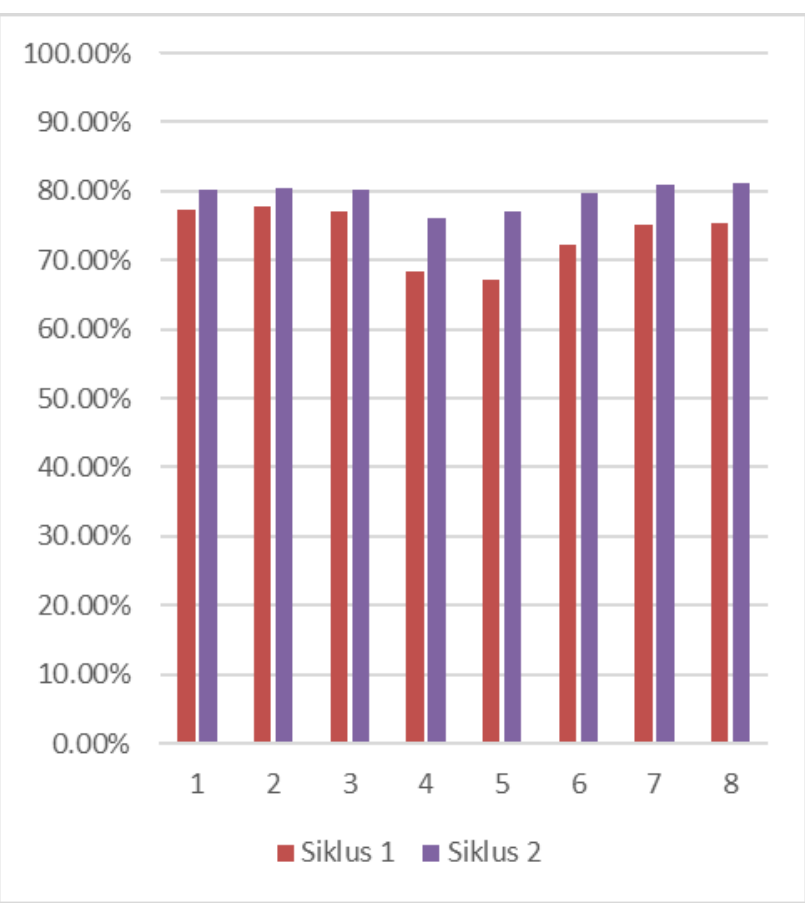

Gambar 2. Diagram Data Angket Siklus I dan Siklus II

Sumber: Data Primer yang Diolah

Keterangan:

1 : Tekun Menghadapi tugas

2 : Ulet menghadapi kesulitan

3 : Memiliki minat terhadap pelajaran

$4 \quad$ : Lebih senang bekerja mandiri

5 : Cepat bosan pada tugas-tugas rutin

6 : Dapat mempertahankan pendapat

7 : Tidak mudah melepaskan hal yang diyakini

8 : Senang mencari dan memecahkan masalah soal-soal

Berdasarkan data yang telah di tampilkan baik data observasi maupun angket dapat ditarik kesimpulan bahwa terdapat peningkatan Motivasi Belajar Akuntansi siswa kelas XI IPS 1 Madrasah Aliyah Negeri Pakem Sleman yang ditunjukan dengan peningkatan skor Motivasi Belajar Akuntansi pada setiap indikator yang ditetapkan dengan rincian sebagai berikut:

1) Tekun Menghadapi tugas

Terjadi peningkatan dari sebelum implementasi Model Pembelajaran Kooperatif Teknik Jigsaw sebesar 77,08\% naik $3,13 \%$ menjadi $80,21 \%$ pada siklus I dan dari siklus I ke siklus II naik 7,29\% menjadi $87,50 \%$. Selain itu juga terlihat peningkatan dari data yang diperoleh dari angket dimana terjadi peningkatan dari siklus I sebesar $77,34 \%$ naik $2,87 \%$ menjadi $80,21 \%$ pada siklus II. Dalam pembelajaran kooperatif teknik Jigsaw siswa menjadi lebih cepat dalam memahami soal dan lebih cepat dan teliti dalam mengerjakannya karena masing-masing individu memperoleh pemahaman dari diskusi berkelompok. Siswa saling bertukar pendapat saat berkelompok ketika memecahkan masalah sehingga siswa menjadi paham bagaimana cara memecahkan masalah ketika diberi soal secara individu.

2) Ulet menghadapi kesulitan

Terjadi peningkatan dari sebelum implementasi Model Pembelajaran Kooperatif Teknik Jigsaw sebesar 76,04\% naik $1,04 \%$ menjadi $77,08 \%$ pada siklus I dan dari siklus I ke siklus II naik 3,13\%\% menjadi $80,21 \%$. Selain itu juga terlihat peningkatan dari data yang diperoleh dari angket dimana terjadi peningkatan dari siklus I sebesar $77,73 \%$ naik $2,74 \%$ menjadi $80,47 \%$ pada siklus II. Dalam pembelajaran kooperatif teknik Jigsaw, siswa menjadi lebih berani dalam bertanya kepada teman maupun guru ketika menemui masalah. Setelah bertanya maka siswa memperoleh pemahaman untuk memecahkan masalah yang sedang dihadapi. 
3) Memiliki minat terhadap pelajaran

Terjadi peningkatan dari sebelum implementasi Model Pembelajaran Kooperatif Teknik Jigsaw sebesar 73,96\% naik $1,04 \%$ menjadi $75,00 \%$ pada siklus I dan dari siklus I ke siklus II naik 7,29\% menjadi $82,29 \%$. Selain itu juga terlihat peningkatan dari data yang diperoleh dari angket dimana terjadi peningkatan dari siklus I sebesar 77,08\% naik 3,13\% menjadi $80,21 \%$ pada siklus II. Dalam pembelajaran kooperatif teknik jigsaw, siswa terlihat antusias dalam mengikuti setiap kegiatan pembelajaran yag dilakukan. Terlihat mulai dari pertama kali pembelajaran ketika siswa diberi hand out, siswa fokus dalam memahami materi yang terdapat pada hand out yang dibagikan. Siswa yang kurang paham bertanya pada guru dan diberikan penjelasan mengenai hal yang ditanyakan.

4) Lebih senang bekerja mandiri

Terjadi peningkatan dari sebelum implementasi Model Pembelajaran Kooperatif Teknik Jigsaw sebesar 68,75\% naik $2,08 \%$ menjadi $70,83 \%$ pada siklus I dan dari siklus I ke siklus II naik 8,34\% menjadi $79,17 \%$. Selain itu juga terlihat peningkatan dari data yang diperoleh dari angket dimana terjadi peningkatan dari siklus I sebesar $68,23 \%$ naik $7,81 \%$ menjadi $76,04 \%$ pada siklus II. Dalam pembelajaran kooperatif teknik jigsaw, siswa memahami posisi dimana untuk bekerja kelompok dan dimana untuk mandiri. Ketika diberi soal mandiri siswa terlihat sangat fokus dalam mengerjakan soal dan yakin jika jawabnya adalah yang terbaik.

5) Cepat bosan pada tugas-tugas rutin

Terjadi peningkatan dari sebelum implementasi Model Pembelajaran Kooperatif Teknik Jigsaw sebesar 67,19\% naik $4,16 \%$ menjadi $74,48 \%$ pada siklus I dan dari siklus I ke siklus II naik 7,81\% menjadi $82,29 \%$. Selain itu juga terlihat peningkatan dari data yang diperoleh dari angket dimana terjadi peningkatan dari siklus I sebesar 67,19\% naik 9,76\% menjadi $76,95 \%$ pada siklus II. Dalam pembelajaran kooperatif teknik jigsaw siswa diberi soal secara individu dan secara kelompok dengan adanya langkah-langkah yang harus dilakukan dengan benar. Hal ini membuat siswa menjadi lebih teliti dan harus berpikir sesuai langkah-langkah dalam mengerjakan soal yang dibagikan sehingga membuat siswa tidak cepat bosan karena adanya langkah-langkah yang harus dikerjakan dengan tepat.

6) Dapat mempertahankan pendapat

Terjadi peningkatan dari sebelum implementasi Model Pembelajaran Kooperatif Teknik Jigsaw sebesar 71,88\% naik $4,16 \%$ menjadi $76,04 \%$ pada siklus I dan dari siklus I ke siklus II naik 5,21\% menjadi $81,25 \%$. Selain itu juga terlihat peningkatan dari data yang diperoleh dari angket dimana terjadi peningkatan dari siklus I sebesar 72,14\% naik 7,55\% menjadi $79,69 \%$ pada siklus II. Dalam pembelajaran kooperatif teknik jigsaw siswa melakukan diskusi dalam kelompok dan terlihat siswa saling bertukar pendapat tentang soal yang dikerjakan dengan memberi alasan-alasan yang tepat tentang pendapatnya.

7) Tidak mudah melepaskan hal yang diyakini

Terjadi peningkatan dari sebelum implementasi Model Pembelajaran Kooperatif Teknik Jigsaw sebesar 77,08\% naik $1,05 \%$ menjadi $78,13 \%$ pada siklus I dan dari siklus I ke siklus II naik 3,12\% menjadi $81,25 \%$. Selain itu juga terlihat peningkatan dari data yang diperoleh dari angket dimana terjadi peningkatan dari siklus I sebesar 75,00\% naik 5,86\% menjadi $80,86 \%$ pada siklus II. Dalam pembelajaran kooperatif teknik jigsaw siswa dalam 
berkelompok mengemukakan pendapat dengan alasan yang kuat dan benar sehingga dapat meluruskan pendapat dari rekanrekanya yang kurang tepat.

8) Senang mencari dan memecahkan masalah soal-soal

Terjadi peningkatan dari sebelum implementasi Model Pembelajaran Kooperatif Teknik Jigsaw sebesar 73,96\% naik $3,12 \%$ menjadi $77,08 \%$ pada siklus I dan dari siklus I ke siklus II naik 3,13\% menjadi $80,21 \%$. Selain itu juga terlihat peningkatan dari data yang diperoleh dari angket dimana terjadi peningkatan dari siklus I sebesar 75,39\% naik 5,86\% menjadi $81,25 \%$ pada siklus II. Dalam pembelajaran kooperatif teknik jigsaw siswa terlihat antusias ketika guru membagi soal baik dalam kelompok maupun saat tes individu. Tanpa disuruh oleh guru, siswa langsung mengerjakan soal yang diberikan.

Dari hasil analisis masing-masing indikator di atas, maka hipotesis pada penelitian ini adalah benar bahwa Implementasi Model Pembelajaran Kooperatif Teknik Jigsaw dapat Meningkatkan Motivasi Belajar Akuntansi Siswa Kelas XI IPS 1 Madrasah Aliyah Negeri Pakem Sleman Tahun Ajaran 2014/2015. Dapat dikatakan pula bahwa penelitian ini sejalan dengan penelitianpenelitian relevan sebelumnya bahwa Implementasi Model Pembelajaran Kooperatif Teknik Jigsaw dapat Meningkatkan Motivasi Belajar Akuntansi Siswa.

\section{SIMPULAN DAN SARAN}

\section{Simpulan}

Berdasarkan hasil penelitian dan pembahasan dapat disimpulkan bahwa Implementasi Model Pembelajaran Kooperatif Teknik Jigsaw dapat meningkatkan Motivasi Belajar Akuntansi siswa kelas XI IPS 1 Madrasah Aliyah Negeri Pakem Sleman tahun ajaran 2014/2015 yang terlihat dari peningkatan presentase skor Motivasi Belajar Akuntansi yang diperleh melalui observasi sebelum implementasi Model Pembelajaran Kooperatif Teknik Jigsaw diperoleh skor Motivasi Belajar Akuntansi sebesar 72,71\% dan meningkat sebesar $3,12 \%$ menjadi $75,83 \%$ setelah adanya implementasi Model Pembelajaran Kooperatif Teknik Jigsaw pada siklus I. Peningkatan juga terjadi pada siklus I ke siklus II yaitu sebesar $6,05 \%$ atau dari $75,83 \%$ pada siklus I menjadi $81,88 \%$ pada siklus II.

Selain data dari observasi, terdapat juga data dari angket yang didistribusikan menunjukan adanya peningkatan Motivasi Belajar Akuntansi dari skor siklus I sebesar $73,75 \%$ meningkat $5,63 \%$ menjadi $79,38 \%$ pada siklus II. Lalu dari hasil data observasi dan angket, hasil keduanya dijumlahkan untuk memperoleh hasil rata-rata. Hasil ratarata yang diperoleh yaitu sebesar $74,79 \%$ pada siklus 1 dan $80,63 \%$ pada siklus 2 . Data dari observasi dan angket telah menunjukan adanya peningkatan Motivasi Belajar Akuntansi sehingga dapat disimpulkan bahwa implementasi Model Pembelajaran Kooperatif Teknik Jigsaw dapat meningkatkan Motivasi Belajar Akuntansi.

\section{Saran}

a) Bagi Guru

1) Guru perlu mempersiapkan segala sesuatu yang dibutuhkan pada saat proses pembelajaran secara terencana ketika akan mengimplementasikan model pembelajaran kooperatif teknik jigsaw dan melakukan penilaian secara lebih teliti terhadap siswa. 
2) Guru harus lebih tegas saat siswa mengerjakan soal-soal agar siswa mengerjakan soal secara mandiri dan tidak menggantungkan pekerjaannya kepada siswa lain.

b) Bagi Siswa

1) Siswa perlu membiasakan diri untuk mengerjakan tugas-tugas yang diberikan guru secara mandiri dan tidak menggantungkan hasil pekerjaan kepada teman dalam menyelesaikan soal-soal latihan.

2) Siswa perlu membisakan diri untuk lebih bersemangat dalam mengerjakan tugas-tugas rutin tentang apa yang sedang dipelajarinya.

c) Bagi Peneliti Selanjutnya

1) Peneliti yang akan melakukan penelitian menggunakan teknik Jigsaw diharapkan lebih detail dalam melakukan observasi sehingga data yang diperoleh benar-benar mewakili kondisi siswa yang sebenarnya.

2) Untuk penelitian yang selanjutnya diharapkan memiliki waktu yang dan persiapan yang lebih pada saat penelitian agar implementasi teknik Jigsaw dapat berjalan secara masksimal.

\section{E. DAFTAR PUSTAKA}

Al Haryono Jusup. (2011). Dasar-Dasar Akuntansi I. Yogyakarta : STIE YKPN.

Ardy Pratama Putra Wardhana. (2013). Implementasi Model Pembelajaran Kooperatif Teknik Team Accelerated Instruction (TAI) untuk Meningkatkan Motivasi Belajar Team AcceleratAkuntansi Siswa Kelas XI IPS 2 SMA Negeri 1 Banguntapan Tahun Ajaran
2012/2013. Skripsi. Yogyakarta: UNY.

Arends, Richard I. (2008). Learning to Teach: Belajar untuk Mengajar. Yogyakarta: Pustaka Belajar.

Diah Setianingsih. (2013). Implementasi Model Pembelajaran Kooperatif Teknik (TPS) Think Pair Share Untuk Meningkatkan Motivasi Belajar dalam Pembelajaran Akuntansi Bilingual Siswa Kelas XI Ak 1 SMK Negeri 1 Depok Tahun Ajaran 2012/2013. Skripsi. Yogyakarta : FE UNY.

Dimyati \& Mudjiono. (2009). Belajar dan Pembelajaran. Jakarta: Rineka Cipta.

Hamzah B. Uno. (2011). Teori Motivasi dan Pengukurannya Analisis di Bidang Pendidikan. Jakarta: Bumi Aksara.

Iskandar. (2009). Psikologi Pendidikan: Sebuah Orientasi Baru. Ciputat: Gaung Persada (GP) Press.

Lorentya Yulianti Kurnianingtyas. (2012). Implementasi Metode Pembelajaran Kooperatif Teknik Jigsaw untuk Meningkatkan Keaktifan Belajar Akuntansi pada Siswa Kelas X Akuntansi 3 SMK Negeri 7 Yogyakarta Tahun Ajaran 2011/2012. Skripsi. Yogyakarta: FE UNY.

Made Wena. (2011). Strategi Pembelajaran Inovatif Kontemporer: Suatu Tinjauan Konseptual Operasional. Jakarta: Bumi Aksara.

Miftahul Huda. (2012). Cooperative Learning. Yogyakarta: Pustaka Pelajar

Mulyasa. (2009). Menjadi Guru Profesional Menciptakan Pembelajaran Kreatif 
\& Menyenangkan. Bandung: PT

Remaja Rosdakarya

Mustaqim. (2008). Psikologi Pendidikan. Yogyakarta: Pustaka Pelajar.

Nana Syaodih Sukmadinata. (2004). Landasan Psikologi Proses Pendidikan. Bandung: Remaja Rosdakarya

Rochiati Wiriaatmadja. (2009). Metode Penelitian Tindakan Kelas untuk Meningkatkan Kinerja Guru dan Dosen. Bandung: Rosdakarya.

Rusman. (2012). Model-model Pembelajaran Mengembangkan Profesionalitas Guru. Jakarta : Raja Grafindo Persada

Sardiman A.M. (2009). Interaksi \& Motivasi Belajar Mengajar. Jakarta: PT Raja Grafindo Persada.

Slavin, Robert E. (2009). Cooperative Learning Teori, Riset, dan Praktik. Bandung: Penerbit Nusa Media.

Sugihartono, dkk. (2013). Psikologi Pendidikan. Yogyakarta: UNY Press

Sugiyono. (2012). Metode Penelitian Pendidikan. Bandung: Alfabeta.

Suharsimi Arikunto. (2008). Prosedur Penelitian Suatu Pendekatan Praktik._Jakarta: Rineka Cipta.

Wina Sanjaya. (2009). Strategi Pembelajaran Berorientasi Standar Proses Pendidikan. Jakarta: Kencana

Yohan Bachtiar. (2009). Implementasi pembelajaran kooperatif metode Team Accelerated Instruction (TAI) pada mata palajaran akuntansi untuk meningkatkan motivasi dan hasil belajar siswa kelas X KU 1 program keahlian akuntansi di SMKN 2 Nganjuk Tahun Ajaran 2009/2010. Skripsi. Malang: UNM. 